\title{
Risks and Implications of Bovine Spongiform Encephalopathy for the United States: Insights from Other Countries.
}

\author{
John A. Fox* \\ and \\ Hikaru Hanawa Peterson \\ Final submission, Food Policy \\ January 13, 2004
}

*Fox (seanfox@agecon.ksu.edu ; tel 785.532-4446; fax 785.532-6925) is associate professor and Peterson is assistant professor, Department of Agricultural Economics, Kansas State University, Waters Hall, Manhattan, KS 66502. We gratefully acknowledge the input from two anonymous referees. 


\title{
Risks and Implications of Bovine Spongiform Encephalopathy for the United States: Insights from Other Countries.
}

\begin{abstract}
BSE has not been found in the US* but current detection efforts provide little assurance that it does not exist at a low level. The US has taken precautionary measures to reduce the risk of importing the disease and the risk of the disease spreading if it were to be found. Those measures include a ban on feeding ruminant protein to ruminants-a measure the General Accounting Office concluded was not adequately enforced and which failed to halt the disease in the UK. We present an overview of BSE in the UK, the EU, and Japan and present an argument for additional precautionary measures in the US.
\end{abstract}

\section{*Addendum (or Editor's note)}

This paper was originally submitted in December 2002, and was accepted for publication prior to the announcement on December 22, 2003 that a cow in the US State of Washington had tested positive for BSE. Following that announcement, export markets including Japan and South Korea immediately banned US beef and, over the following two weeks, cattle futures prices fell by about fifteen percent. On December 30, 2003, the US Secretary for Agriculture announced additional measures against BSE, including a ban on "downers" (cattle that cannot walk), changes in slaughterhouse practices to further reduce the risk of contamination with nervous tissue, and plans to introduce a national animal identification program. It was subsequently discovered that the cow in question had been imported from Canada in 2001, and thus, as of this writing, the US does not yet have a native born case of the disease. 


\section{Risks and Implications of Bovine Spongiform Encephalopathy for the United States: Insights from Other Countries.}

\section{Introduction}

Bovine spongiform encephalopathy (BSE), or mad cow disease, was first recognized in the UK in the mid 1980s. It is a degenerative disease of the central nervous system, resulting in the development of spongy lesions in the brain. BSE is classified as a transmissible spongiform encephalopathy (TSE), variants of which include scrapie in sheep, and chronic wasting disease in deer and elk. The most common TSE affecting humans is sporadic (or classic) Creutzfeld-Jacob Disease (CJD), which affects about one individual per million worldwide, and whose cause is not known. All TSE diseases are fatal.

In 1996, UK government scientists announced that the “most likely explanation” for ten cases of a new type of CJD (labeled variant or new-variant CJD) was “exposure to BSE” (SEAC, 1996). The announcement resulted in an immediate ban on UK exports of live cattle and all beef products, a 30 to 40 percent reduction in domestic beef consumption, and significant losses to beef producers, agribusinesses, and the treasury. In this paper we summarize key events associated with BSE in the UK, Europe, Japan, and Canada. We then review the situation in the US where a native born case of the disease has not yet been discovered. We describe counter measures already in place, and argue, based on experience with the disease in other countries, that counter measures should be strengthened. Abbreviations used in the manuscript are listed in Table 1. 


\section{The disease}

Several questions remain unanswered about the cause, original source, incubation periods, and routes of infection of BSE. As to the cause, most but not all scientists believe the infective agent to be a modified prion $^{1}$ protein. From a biological perspective prions are simple structures without DNA, and thus more difficult to destroy than viruses or bacteria. Treatment of animal by-products at $133^{\circ} \mathrm{C}$ at 3 bar pressure for a minimum of 20 minutes will destroy prions but for foods for human consumption there are no feasible processes to destroy the agent.

Some scientists believe the prion responsible for BSE resulted from mutation (Phillips et al., 2000), while others suspect that BSE resulted from cross transmission of sheep scrapie (Horn et al., 2001). Scrapie has long been known as a disease in sheep and is found worldwide with the exception of Australia and New Zealand. The first recorded case in the UK dates from 1732 and there are an estimated five to ten thousand cases there every year. Scrapie could have spread from sheep to cattle as a result of changes in the rendering ${ }^{2}$ system in the 1970's and the introduction of meat and bone meal (MBM) as a protein supplement in rations for young dairy calves (Horn et al., 2001).

Once established, BSE spread within cattle and to humans and other species as tissue from infected animals entered the feed chain. Maternal transmission of BSE is considered possible, and scientists have not ruled out the possibility of lateral/environmental transfer between animals. However, the relatively small number of cases $^{3}$ in the UK in animals born after the feed ban was reinforced in August 1996 suggests that these routes of transmission do not operate at significant levels. 
Most cases occur in animals over four years old, with rare instances in animals as young as 20 months. The evidence suggests that most animals become infected as young calves. During the incubation period, infective prions accumulate in nervous tissuespinal cord, eyes and brain—before symptoms, which involve loss of motor and neurological control, appear. Once symptoms appear, progression of the disease is relatively quick with death occurring within a year. To date, there is no treatment for either humans ${ }^{4}$ or cattle, and the disease can only be definitively diagnosed post-mortem. ${ }^{5}$ Infective doses for humans are not known with certainty but experiments with cattle and sheep have shown that less than half of a gram of infected brain tissue is sufficient to transmit BSE when administered orally. Genetic factors play a role in susceptibility to both vCJD and BSE, and research is ongoing to develop cattle resistant to the disease. Thus far transmission to humans has only been associated with consumption (or injection with contaminated vaccines) of prion-infected nervous tissue from bovines. It is believed unlikely that consumption of muscle tissue or milk from infected animals can cause the disease, although Bosque et al. (2002) have demonstrated the presence of infectious prions in muscle tissue in mice.

\section{Chronology}

\section{United Kingdom}

The earliest recorded case of what was later referred to as "mad cow disease" was reported in 1984 on a farm in Sussex. Within a year, six more cows from the same farm had succumbed to the illness, but it was not until late 1986 that the condition was confirmed as a bovine TSE (see Table 2 for a chronology). As of January 1, 2004, a total 
of 180,361 cases had been confirmed on over 35,000 farms (Figure 1). For each confirmed case it is suspected that several sub-clinical cases were undetected - Donnelly et al. (2002) estimated the total number of cases at about 2 million. About $80 \%$ of cases have been in dairy cows, with over $60 \%$ of UK dairy farms having at least one case.

Transmission of the disease was soon linked to MBM and in July 1988 the UK banned the feeding of ruminant derived protein to ruminants. Having lost a portion of their domestic market, UK renderers increased exports. Most of those exports went to EU countries, where MBM was used in animal rations that were then exported outside the EU. At the time the UK was not particularly proactive in warning other countries about the risk from MBM. The issue was reported at the annual meeting of the International Office of Epizootics (OIE) in May 1989 - thereafter several EU countries banned MBM from the UK, and the Netherlands introduced their own ruminant feed ban. In February 1990, UK began to contact non-EU countries about the risk from MBM imported from the UK (Phillips et al., 2002, Vol.3, Ch.6). ${ }^{6}$

In 1989, the UK banned the use of specified bovine offal (SBO) for human consumption, thereby removing from the food chain potentially infective tissues from animals not showing symptoms of the disease. ${ }^{7}$ Following discoveries that BSE could be transmitted to mice, domestic cats, and pigs, the ban on SBO was extended to all animal feed in September 1990. With both the ruminant feed ban and SBO ban in operation, officials felt confident that the disease would be contained.

In March 1991 came the first case of BSE in an animal born after the 1988 feed ban (referred to as a 'BAB' — born after ban). BABs were initially attributed to delays in 
clearing MBM stocks but with some evidence of deliberate breaches of the regulation. However, in 1994 there were almost 10,000 BABs, suggesting serious problems with cross-contamination - either in mills producing feed for both ruminants and nonruminants, or on farms with mixed species. Furthermore, the number of BABs was indicative of the high level of infectivity in tissues derived from sub-clinically infected animals (since all clinical cases were being destroyed). In 1994, officials began finding cases in animals born after the 1990 SBO ban and to date there have been over 12,000 such cases. This suggests that in addition to problem of cross-contamination of feed, SBO tissues were not being properly removed in slaughter plants.

Figure 2 outlines the known mode of BSE transmission through animals feed. All three intermediate steps must operate for the disease to persist. Destroying clinically infected animals was not sufficient to block step \#1 because sub-clinically infected animals are also infective. The ruminant feed ban sought to block step \#3, but failed because of cross-contamination. Cross-contamination was (and remains) difficult to detect because of the lack of reliable tests for banned proteins in compound feeds. The SBO ban, which would block step \#2, failed because of non-compliance. Part of the problem was that the animal SBO ban was poorly designed and essentially unenforceable with no means of identifying whether or not MBM contained SBO (Phillips et al., 2000). Human health risk

While the number of BSE cases mounted, the government continued to reassure the public that the disease posed no health risk to humans. Public concern had grown since BSE was first reported, especially when it was learned in 1990 that the disease 
could affect cats. Some scientists were also concerned - Professor Richard Lacey was quoted as saying that due to BSE, "in the years to come our hospitals will be filled with thousands of people going slowly and painfully mad before dying."8 Concern was heightened in 1993 when it was reported that two dairy farmers had died from CJD. But the official position remained unchanged with the health minister quoted in December 1995 as saying "there is no conceivable risk of BSE being transmitted from cows to people.”

Early in 1996, officials at the ministry of agriculture were informed that ten people had died of a new strain of CJD. Unlike sporadic CJD, which strikes elderly people, these victims were much younger - all under the age of 42 with many in their teens or twenties. On March 20, 1996, government scientists announced the possibility of a link between BSE and this new type of CJD. As of January 1, 2004, vCJD had been confirmed in the deaths of 139 individuals in the UK, one each in former UK residents in the US and Hong Kong, six individuals in France, and one each in Italy, Ireland and Canada. In the absence of reliable tests for pre-clinical vCJD, estimates about the likely number of victims varies from less than 300 (Boelle et al., 2003) to 50,000 (Ferguson et al., 2002) to over a million (Huillard d'Aignaux et al., 2003)

Following the March 1996 announcement, the UK government introduced new control measures including a ban on the use of all MBM of mammalian origin in all farm animal feed and the removal of animals over thirty months old from the human food chain. The over-thirty-months-scheme (OTMS) remains in operation and has accounted for almost six million animals. 


\section{Spreading it around}

BSE spread from the UK through exports of live animals and contaminated feed. Infected animals from the UK were detected in Canada, Oman, and the Falkland Islands, in addition to six European countries. The EU banned imports of live animals from the UK in 1989, as did Israel, Australia, New Zealand, Sweden and the US. However, among animals exported prior to 1989 it is unlikely that all BSE cases were detected.

Exports of MBM from the UK were relatively small during the 1980s, reaching approximately 15,000 tons (4 percent of production) in 1988. Most went to EU countries but some also went, either directly or via feed rations produced in the EU, to non-EU countries including Indonesia, Thailand and Sri Lanka. As a result of the ruminant feed ban in the UK, exports to the EU and other countries doubled between 1988 and 1989 (Figure 3). When EU countries banned MBM from the UK or introduced their own feed bans in 1989, exports to non-EU countries increased.

In September 1991, the UK banned exports of MBM containing SBO to non-EU countries. But in view of subsequent revisions of how SBO was defined, it appears that until the mid 1990s, potentially infective MBM from the UK continued to be exported to countries that did not have ruminant feed bans.

\section{BSE in Europe}

In the early 1990s BSE spread to other countries in Europe including Ireland (ten cases in 1989), Switzerland (two cases in 1990), France (five cases in 1991), and Portugal (twelve cases in 1994). In 1994, the EU banned mammalian protein in ruminant feed and in March 1996, following the announcement of the link to CJD, banned exports of all 
cattle and beef from the UK. On January 1, 1998, new legislation required the destruction of Specified Risk Material (SRM) from cattle, sheep, and goats-introducing to other EU countries the restrictions on SBO in place in the UK. As had occurred with SBO, the definition of what constituted SRM continued to expand. In December 2000, for example, the definition was amended to include intestines of bovines of all ages.

From the mid to late 1990s additional cases were discovered in France, Portugal and Switzerland at relatively low rates, ${ }^{9}$ with cases also appearing in Belgium and the Netherlands in 1997. Late in 2000, the first "homegrown" cases were discovered in Germany, Spain, and Denmark, followed by Italy’s first case in early 2001. The market reaction was instant and dramatic. Beef consumption fell by about 30 percent, and exports by the EU to non-EU countries—notably Russia and Egypt—were halted. German consumers, having been continually reassured by their government that their beef supply was free of BSE, reacted particularly strongly, with beef demand falling by about 50 percent as manufacturers of processed meat products scrambled to reformulate with pork instead of beef. The immediate price effects were so great (see Table 3) that at one point in the subsequent months the trade pattern for beef within the EU was almost completely reversed—with Germany exporting beef to Ireland.

In response to the crisis, the EU took a series of measures to safeguard public health and restore confidence in beef (see Byrne, 2002). These included:

1. BSE tests for all animals over 30 months intended for human consumption. ${ }^{10}$ Animals not tested were eligible for a Purchase-for-Destruction scheme.

2. All casualty animals over 24 months tested for BSE. 
3. Use of MBM in all animal feed suspended and all MBM stocks destroyed.

4. Definition of SRM extended to include vertebral column and the entire intestine.

5. A ban on mechanically recovered meat.

The direct cost of BSE control measures for the EU was estimated to be over one billion euros for 2001.

\section{Beyond Europe}

The first case of BSE in Japan was announced on September 10, 2001, with a second case announced in late November of the same year. A total of nine cases have been discovered to date, the most recent in November 2003. The first seven cases were in dairy cows born in 1995 or 1996, but the two most recent cases have been in younger animals born in late 2001 and 2002. Initially, the outbreak was linked to MBM imported from the UK in the early $1990 \mathrm{~s}^{11}$ suggesting that the affected animals were secondgeneration cases and that the disease had already recycled in Japan. However the small number of cases appears to invalidate that scenario and what are now considered the most likely causes are cows imported from the UK in the 1980s or contaminated MBM imported from Italy.

Following the announcement of the first case, beef consumption fell dramatically. September 2001 retail beef sales were reported to be down 40 to 50 percent, with wholesale prices 30 to 60 percent below normal. According to a national survey by Asahi newspaper in mid-October, one out of four consumers had stopped eating beef, and only 26 percent indicated that they had not altered their beef consumption. Restaurants specializing in beef reported more than 50 percent loss in sales revenue during the first 
half of October, while school lunch programs around the nation altered their menus to exclude beef. The impact was not confined to domestically produced beef - the value of US beef exports to Japan was down $42 \%$ for the first half of 2002 compared to the previous year.

In response, the Japanese government removed animals over 30 months from the human food chain and instituted BSE testing of all slaughtered cattle for human consumption. ${ }^{12}$ It also banned imports, processing, and distribution of MBM for all uses. $^{13}$ A budget of over $\$ 1.3$ billion included the cost of an income stabilization scheme for cattle farms, incineration costs for MBM, and the cost of a new electronic tagging and traceability system for all livestock that was implemented in October 2002. The government also purchased and incinerated the entire beef inventory prior to the initiation of BSE testing at a cost of over 10 billion yen (approximately $\$ 100$ million).

Canada announced the discovery of its first domestic case of BSE on May 20, 2003. Export markets banned Canadian beef within hours of the announcement but in contrast to reactions in Europe and Japan, domestic beef consumption was unaffected consumers seemed to accept the idea that the discovery represented an isolated case. The loss of export markets was estimated to cost over $\mathrm{C} \$ 500$ million per month (Canadian Animal Health Coalition, 2003). In June 2003, the Canadian government committed C\$460 million to compensate producers.

\section{The Situation in the United States}

Overview 
To date there have been no native born cases of BSE in the US. Other animal TSE's are found including scrapie, transmissible mink encephalopathy (TME), and chronic wasting disease (CWD) in deer and elk. Scrapie was first reported in 1947 and since then has been found in over 1000 flocks. TME was first found in the 1960's in ranched mink and was attributed to the feeding of scrapie-infected sheep tissue (McKenzie et al., 1996). CWD was identified in the 1960’s in captive deer at a research station in Colorado. During the past decade, it has spread to wild deer in several midwestern states and Canada, and to farmed elk. In Wisconsin, testing in 2001 indicated that up to 3 percent of the deer population might have the disease. Much remains unknown about CWD-in particular its modes of transmission and original source. While there is no evidence to suggest that CWD can be transmitted to humans, the Centers for Disease Control and the World Health Organization recommend that tissue from deer or elk with CWD not be used in animal or human food.

Risk of BSE in the US

To prevent BSE, the US banned imports of live animals from countries with BSE in 1989, imports of MBM from those countries in 1991, and extended those restrictions to countries at risk for BSE (i.e., all of Europe) in 1997. A ban on feeding ruminant protein to ruminants was implemented in 1997. A report by the Harvard Center for Risk Analysis and the Tuskegee University Center for Computational Epidemiology (Cohen et al., 2001) has been widely quoted to support the idea that the risk of BSE in the US is extremely low. However, as is stated in the report, its purpose was to evaluate the 


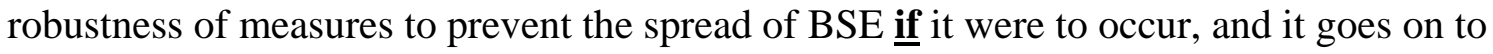
state that "BSE is extremely unlikely to become established in the US" (emphasis added).

The EU Scientific Steering Committee classifies the US as a Geographical BSERisk (GBR) level II country—one in which the presence of BSE is 'unlikely, but not

excluded. ${ }^{, 14}$ Canada enjoyed the same risk status until its first case was discovered, while three other countries in the same category - Austria, Finland and Slovenia detected their first cases of BSE in 2001. Interestingly, while US meat exports carry a label stating, "The United States meets or exceeds all of the international guidelines to be considered free of BSE," the EU requires that GBR level II countries such as the US remove all SRM from beef exported to the EU.

Adequacy of US Measures

In 2002, the General Accounting Office (GAO, 2002) reported that measures adopted in the US did not sufficiently ensure that BSE would be prevented, citing weaknesses in import inspections, inadequate testing of animals that die on farm and noncompliance with the FDA feed ban.

\section{The Feed Ban}

The FDA feed ban represents an effort to exclude ruminant derived Meat \& Bone Meal from ruminant feed (i.e. - an attempt to block pathway \#3 in figure 2). This measure is less restrictive than feed bans adopted elsewhere - for comparison we adopt the following classification:

Level 1. Prohibits ruminant protein in ruminant feed Level 2. Prohibits mammalian protein in ruminant feed 


\section{Level 3. Prohibits mammalian protein for all farm animals}

\section{Level 4. Prohibits mammalian protein for all animals (including pets)}

The current US feed ban is less restrictive than that described at Level 1 because it permits certain ruminant proteins (milk, blood) in ruminant feed. The 1988 UK feed ban was at Level 1 - and while it no doubt contributed to the decline of the disease it was not completely effective due to cross contamination between ruminant and non-ruminant feed. In fact, over 44,000 cases of BSE have been confirmed in animals born after that ban was implemented (Figure 1). The 1994 E.U. ban prohibited all mammalian protein in ruminant feed - i.e., Level 2. In 1996, the UK reinforced its feed ban to Level 3 by banning MBM for all farm animals and fish. In 2001, the EU adopted a complete ban on MBM, and Japan has recently taken a similar measure.

The GAO cited weaknesses in FDA enforcement of the feed-ban, particularly in its efforts to re-inspect firms not in compliance with labeling requirements, and the adequacy of its inspection database. Given the extent of the cross-contamination problem in the UK and the enforcement problems cited by the GAO, it seems unlikely that the FDA ban provides adequate assurance that ruminant feed does not contain prohibited material.

\section{Use of potentially infective tissues}

The Harvard/Tuskegee report identified measures that would reduce the risk from BSE including a ban on rendering animals that die on farm, and the exclusion of Specified Risk material (SRM) from human and animal feed. The report estimated that a 
ban on SRM would reduce the predicted number of BSE cases in an outbreak by 80 percent, and reduce potential human exposure by 95 percent.

For countries at risk for BSE, the WHO recommends removal of SRM from the food chain and, as noted above, the EU requires removal of SRM from product exported from the US. At present, the US does not have a ban on SRM nor does it ban human consumption of bovine brain or other central nervous system (CNS) tissue. According to the GAO, products such as beef stock, beef extract, and beef flavoring can contain CNS tissue, and since 1997, USDA found CNS tissue in 12 of 63 samples of meat product derived from advanced meat recovery (AMR) systems. In response to a GAO recommendation that consumers be informed about products that might contain CNS, USDA stated that labeling and warning statements should be reserved for known hazards (USDA, 2002). Because the US does not have BSE, USDA concludes that there is no hazard.

\section{Surveillance}

Effective surveillance would eliminate clinically infected animals from the food chain and thereby at least partially (since non-clinical animals are infective) block infection pathway \#1 (Figure 2). Testing for BSE in the US began in 1990. The program targets cattle diagnosed with central nervous system disorders at slaughter and "downer" animals - those unable to walk at time of slaughter. The GAO report noted that very few animals that died on farm, a relatively high-risk population, were included in the testing program. Animals that die on farm may be buried or collected for rendering — unlike the situation in Europe where deaths of all animals over 24 months must be notified, the 
animal tested for BSE, and the carcass collected for incineration. The Harvard-Tuskegee analysis showed that excluding such animals from the rendering process would significantly reduce the potential for BSE to spread.

In February 2002, USDA announced that it would increase, from around 5,000 in 2001 to 12,500 in 2002, the number of cattle brains tested for BSE. In fact almost 20,000 tests were conducted in 2002, which, USDA points out, is far more than the level recommended by OIE. Nevertheless, compared to Europe, where almost 8.5 million animals out of a total adult cattle population of 40.8 million were tested in $2001,{ }^{15}$ the level of testing in the US is miniscule. Of the animals tested in Europe, 770,000 were designated "at risk" (e.g., died on-farm) and of those 760 tested positive for BSE. If the U.S had a similar incidence among "at risk" animals, 12,500 tests per year in that category would provide a 99.999 percent probability of detecting at least one positive case. But with no clinical cases to date, the incidence of sub-clinical BSE in the US herd, if any, must be at a much lower level. If, for example, it were present in US "at risk" animals at the same level as in "healthy" animals in Europe (279 positives in 7.6 million tests, or approximately 1 per 25,000), testing 20,000 animals would provide about a 55 percent probability of detection - and it would require 120,000 tests to increase the likelihood of detection to 99 percent. In short, the fact that BSE has not yet been found provides little assurance that it is not present.

Some might argue that if BSE is present at an extremely low level the US would be better off not detecting it—especially if there is little chance of it spreading. However, the infectivity of sub-clinically infected animals (as demonstrated by the failure of the 
UK feed ban and SBO controls) is a characteristic of this disease that suggests the potential peril of ignoring its presence—even at an extremely low level.

\section{Implications for the US.}

A single case of BSE would have serious consequences for the US beef industry. In a worst case scenario, beef exports, valued at around \$3b per year - or twelve to fifteen percent of the value of production, would cease immediately and domestic demand would also fall. If the domestic response mirrored that in Germany and Japan, demand could decline by 30 percent, reducing revenues by over 40 percent in the shortto intermediate-run. ${ }^{16}$ If recovery were to take five or six years, the cumulative loss would be on the order of $\$ 30$ billion. On the other hand, if the impact on domestic demand was minimal, as was the case in Canada, and if importing countries were to abide by OIE and WTO guidelines pertaining to appropriate trade restrictions, the impact would be far less severe - perhaps on the order of $\$ 2 \mathrm{~b}$ (i.e., about fifteen percent of value for half a year).

With the goal of maximizing expected net social benefit, the response to the threat from BSE is a matter of finding an appropriate balance between the costs and benefits of actions that mitigate the risk. But what type of risk, exactly, should US policy address? We believe that additional countermeasures, if warranted, should target the economic risk to the beef industry - rather than the human health risk - posed by the disease. While some consumer groups are concerned about the risk to human health, the reality is that 
even if a few cases were discovered in the US the risk to consumers would still be incredibly low - on the order perhaps of that of being struck by a meteorite.

Are additional counter-measures warranted? If one takes the position that BSE is not present and extremely unlikely to occur, then any set of counter-measures, including those currently in force, could be viewed as unnecessary in the sense that they address a non-existent risk (Murphy, 2002). However, the absence of BSE in the US is not so reassuring given the low level of surveillance. And while the US has probably taken as many precautions as any country in advance of BSE being discovered, we believe, in light of the EU's risk assessment and the discovery of the disease in other 'low-risk' countries,${ }^{17}$ that a case can be made for modifying the USDA "official line" on BSE and for additional counter-measures.

In Germany and Japan, official assurances that those countries were free of BSE were unwarranted, contributed to loss of trust in government when the disease was discovered, and likely exacerbated the extent to which consumers moved away from beef. But the USDA position on BSE risk is similar to that taken in Germany and Japan - the emphasis is on the fact that the disease has not been detected and the Harvard/Tuskegee report is cited to support the idea that the risk of BSE occurring is extremely low. Because significant economic consequences would result from a single case, it might be better to acknowledge the possibility that some cases may be found, while at the same time enhancing counter measures that promote consumer confidence.

Given the low risk to human health, additional measures should focus on reducing the expected economic damage from BSE. In an effort to minimize potential export 
losses, the US is now encouraging adherence to the established OIE science- and riskbased guidelines on trade restrictions - despite the fact that the US itself has been one of the chief culprits in ignoring those guidelines. Regarding domestic demand, we believe it important, as did the GAO, to address human consumption of potentially infective CNS tissue. As already noted, for countries that cannot exclude the possibility of BSE, the WHO recommends a ban on SRM. ${ }^{18}$ The Harvard/Tuskegee report also noted that banning SRM would reduce human exposure by 95\%, and thus, in the event of BSE being discovered, would presumably reassure buyers, both domestic and foreign, that consumers of US beef were insulated from the disease.

Ideally, additional countermeasures would be implemented following rigorous cost-benefit analysis that indicated an increase in expected welfare. Such analysis is beyond the scope and intent of this article, but we can consider some aspects of what it would entail for a proposal to implement an EU type testing regime in the US. The direct cost of testing might be relatively easy to estimate. Of a total US slaughter of around 35 million cattle, about 5 million are cows. Data on age-at-slaughter is not available but, with most beef animals slaughtered between the ages of 20 and 24 months, the total 'over 30 month slaughter' including cows might be in the range of 7 to 9 million. Tests cost between $\$ 30$ and $\$ 50$ per head including lab fees etc, giving a direct cost of testing of between $\$ 210$ and $\$ 450$ million. In the absence of an individual animal ID system, there would be additional costs related to age verification. Benefits would depend on the context in which testing was implemented - for example, it might be a requirement to maintain access to specific export markets. In that case, the benefit could be calculated 
as the surplus from market access. However, there are other potential costs and benefits relating to the impact on demand. Demand might be enhanced as a result of increased consumer confidence, or diminished if the new testing regime finds unexpectedly large numbers of cases. The analysis is then far from simple, and outcomes would be sensitive to assumptions for which there may be little support. Further complications arise when one considers the alternative combinations of potential countermeasures and how they might interact.

In the absence of rigorous welfare analysis, we suggest that acknowledging the possibility of BSE and enhancing measures to further insulate consumers from the disease could help engineer, in political parlance, a "soft (or at least softer) landing” if the disease is discovered in the US. Importantly, taking those steps might reduce the likelihood of a sudden market panic and thus allow whatever additional measures are taken in response to a discovery to be more proportionate to the risk that is presented. The goal should be to avoid the inefficiency of the Japanese situation in which very large costs are being incurred in response to what now appears to be an extremely low threat. ${ }^{19}$ Achieving that goal entails additional up-front costs, but the rate of return on "two stitches in time” is still favorable. 


\section{References}

Boelle, P.Y., G. Thomas, A.J. Valleron, J.Y. Cesbron and R. Will. "Modelling the epidemic of variant Creutzfeld-Jacob disease in the UK based on age characteristics: updated, detailed analysis.” Stat Methods Med Res. 12(3):221-33, June 2003

Bosque, P., C.Ryou, G.Telling, D.Peretz, G.Legname, S.DeArmond, and S.Prusiner. "Prions in Skeletal Muscle.” Proc. Natl. Acad. Sci. 99:6,3812-3817, March 19, 2002

Byrne, D., EU Commissioner for Health and Consumer Protection. "Speaking Note on the Olsson Report on BSE.” Starsbourg. February 5, 2002. Available at www.defra.gov.UK/animalh/bse/index.html

Canadian Animal Health Coalition. “BSE Economic Impact Assessment.” Prepared by Serecon Management Consulting Inc., June 2003

Cohen, J., K.Duggar, G.Gray, S.Kreindel, H.Abdelrahman, T.Habtemariam, D.Oryang, and B.Tameru. "Evaluation of the Potential for Bovine Spongiform Encephalopathy in the United States.” Harvard Center for Risk Analysis and Center for Computational Epidemiology, Tuskegee University. November 2001.

DEFRA. BSE Homepage. UK Department for Environment, Food, and Rural Affairs. www.defra.gov.UK/animalh/bse/index.html

Donnelly, C., N. Fergusun, A. Ghani, and R. Anderson. "Implications of BSE infection screening data for the scale of the British BSE epidemic and current European infection levels.” Proceedings of the Royal Society London. 269:2179-2190. October 2002.

Ferguson, N., A.Ghani, C.Donnelly, T.Hagenaars and R.Anderson. "Estimating the human health risk from possible BSE infection of the British sheep flock.” Nature, 415(2002)420-424.

Food Standards Agency. “Review of BSE Controls: Final Report.” December 2000 http://www.bsereview.org.UK/

General Accounting Office. "Mad Cow Disease: Improvements in the Animal Feed Ban and Other Regulatory Areas Would Strengthen US Prevention Efforts.” GAO-02183, January 2002.

Horn, G. et al. "Review of the origin of BSE.” July 2001. www.defra.gov.UK/animalh/bse/bseorigin.pdf 
Huillard d'Aignaux, J.N., S.N. Cousens and P.G. Smith. "The predictability of the epidemic of variant Creutzfeld-Jacob disease by back-calculation methods.” Stat Methods Med Res. 12(3):203-20, June 2003

McKenzie, D., J.Bartz, and R.Marsh “Transmissible mink encephalopathy” Seminars in Virology, 7(1996):201-206.

Murphy, D. “Commentary: GAO’s report on BSE a bunch of BS.” www.meatingplace.com March 1, 2002.

Nature (16 October 2003) "Routine tests reveal unknown strains of BSE prions.”

Pennings, J., B.Wansink, and M.Meulenberg. "A note on modeling consumer reaction to a crisis: The case of mad cow disease.” Intl. Journal of Research in Marketing. 19(2002):91-100.

Phillips, N., J.Bridgeman, \& M.Ferguson-Smith. "The Inquiry into BSE and variant CJD in the United Kingdom.” October 2000. www.bseinquiry.gov.UK/

Spongiform Encephalopathy Advisory Committee (SEAC). Statement of March 20, 1996.

United States Department of Agriculture. "USDA Response to GAO Recommendations on BSE Prevention.” Fact Sheet. Release No. F.S. 0071.02, February 2002. 
Table 1. Abbreviations

\begin{tabular}{|c|c|}
\hline BABs & BSE cases in UK cattle born after the feed ban (July 1988) \\
\hline BARBs & cases in cattle born after the reinforced feed ban (Aug 1996) \\
\hline BSE & bovine spongiform encephalopathy \\
\hline CJD & Creutzfeldt-Jacob Disease \\
\hline CNS & central nervous system \\
\hline CWD & chronic wasting disease \\
\hline FDA & Food and Drug Administration \\
\hline GAO & General Accounting Office \\
\hline GBR & geographical BSE-risk \\
\hline MBM & meat and bone meal \\
\hline \multirow[t]{2}{*}{ OIE } & Office International des Epizootics \\
\hline & (World Organization for Animal Health) \\
\hline $\mathrm{SBO}$ & specified bovine offal \\
\hline SEAC & Spongiform Encephalopathy Advisory Committee (UK) \\
\hline SRM & specified risk material \\
\hline TME & transmissible mink encephalopathy \\
\hline TSE & transmissible spongiform encephalopathy \\
\hline USDA & US Department of Agriculture \\
\hline vCJD & variant Creutzfeldt-Jacob Disease \\
\hline WHO & World Health Organization \\
\hline
\end{tabular}


Table 2. BSE Chronology

\begin{tabular}{|c|c|}
\hline Date & Event $^{*}$ \\
\hline Dec. 1984 & First recorded case of the new disease is examined \\
\hline Dec. 1986 & BSE identified as a TSE in cattle \\
\hline Dec. 1987 & Epidemiologists link BSE to MBM \\
\hline July 1988 & UK bans ruminant derived MBM in ruminant feed \\
\hline Nov. 1989 & $\begin{array}{l}\text { SBO (brain, spleen, spinal cord, thymus, tonsils, intestines) banned } \\
\text { for human consumption }\end{array}$ \\
\hline Sep. 1990 & Ban on use of SBO in all animal feed (including pet food) \\
\hline Mar. 1991 & First BSE case in animal born after the July 1988 feed ban \\
\hline June $1994^{*}$ & EU bans feeding of mammalian protein to ruminants \\
\hline Aug. 1995 & SBO definition expanded (entire skull incl. brains, eyes) \\
\hline Dec. 1995 & Ban on use of spinal column in mechanically recovered meat \\
\hline Mar. 1996 & Government announces probable link between BSE and CJD \\
\hline Aug. 1996 & Reinforced MBM feed ban (all farm animals) enforced \\
\hline Jun. 1997 & FDA feed ban introduced \\
\hline Jan. 1998 & Introduction of EU-wide SRM regulations \\
\hline June 2000 & First confirmed case born after the reinforced feed ban \\
\hline Nov. 2000 & Germany, Spain report first cases (Italy in Jan. 2001) \\
\hline Jan. 2001 & EU wide ban on MBM for all farm animals \\
\hline Sep. 2001 & First case born outside Europe (Japan) \\
\hline May 2003 & First case in North America (Canada) \\
\hline
\end{tabular}

${ }^{*}$ Italics denote events outside the UK 
Table 3. Beef Prices in Selected Countries: 2000-01 ${ }^{a}$

Change from Aug 2000 to Aug 2001

\begin{tabular}{lc} 
Ireland & $-12 \%$ \\
UK & $-5 \%$ \\
France & $-22 \%$ \\
Italy & $-22 \%$ \\
Germany & $-25 \%$ \\
Australia & $+16 \%$ \\
US & $+16 \%$ \\
\hline Compiled by the authors from various national sources.
\end{tabular}




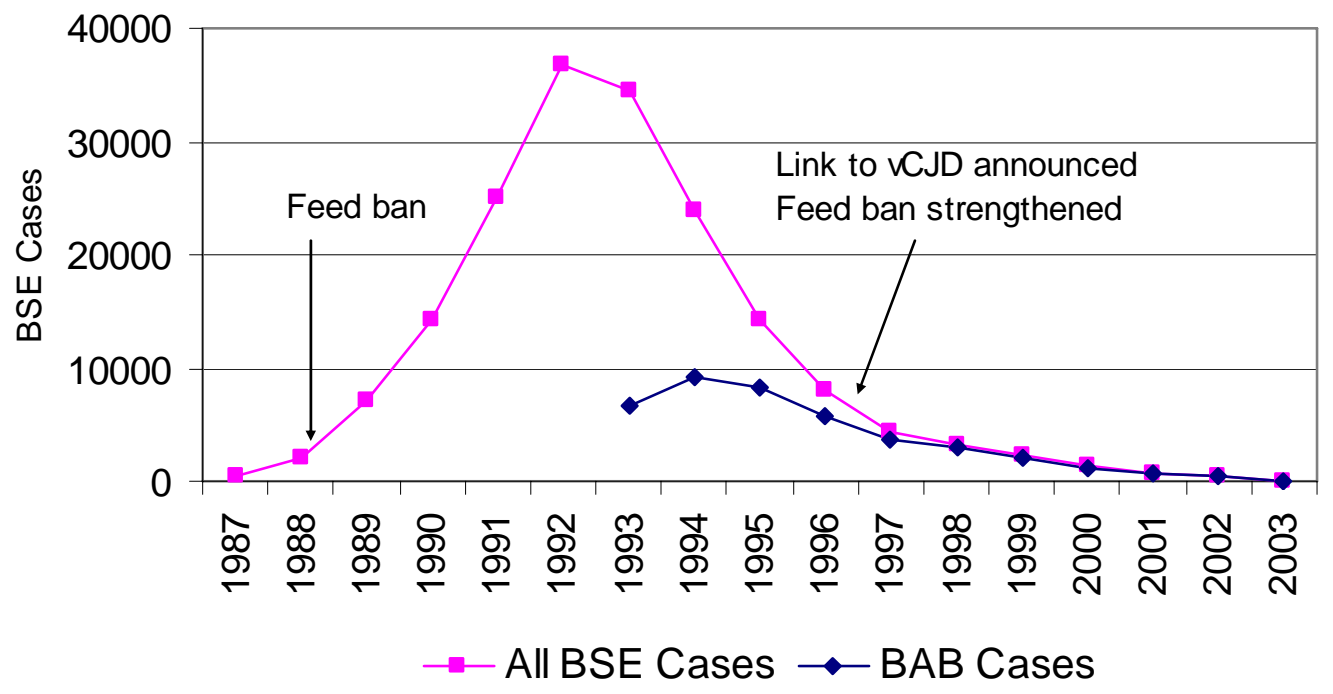

Figure 1. UK BSE cases as of January 1, 2004.

Total of 179,023 detected by passive surveillance, 1,338 by active surveillance. Includes 44,609 BABs - i.e., born after July 18, 1988. Figure constructed by the authors using data from the UK Department for Environment, Food, and Rural Affairs homepage.

http://www.defra.gov.uk/animalh/bse/bse-statistics/ 


\title{
Infected cattle
}

\author{
1. \\ SBO (brain, etc.) \\ 2. \\ Meat and Bone Meal \\ 3. \\ Ruminant feed
}

Figure 2. BSE infection route. 


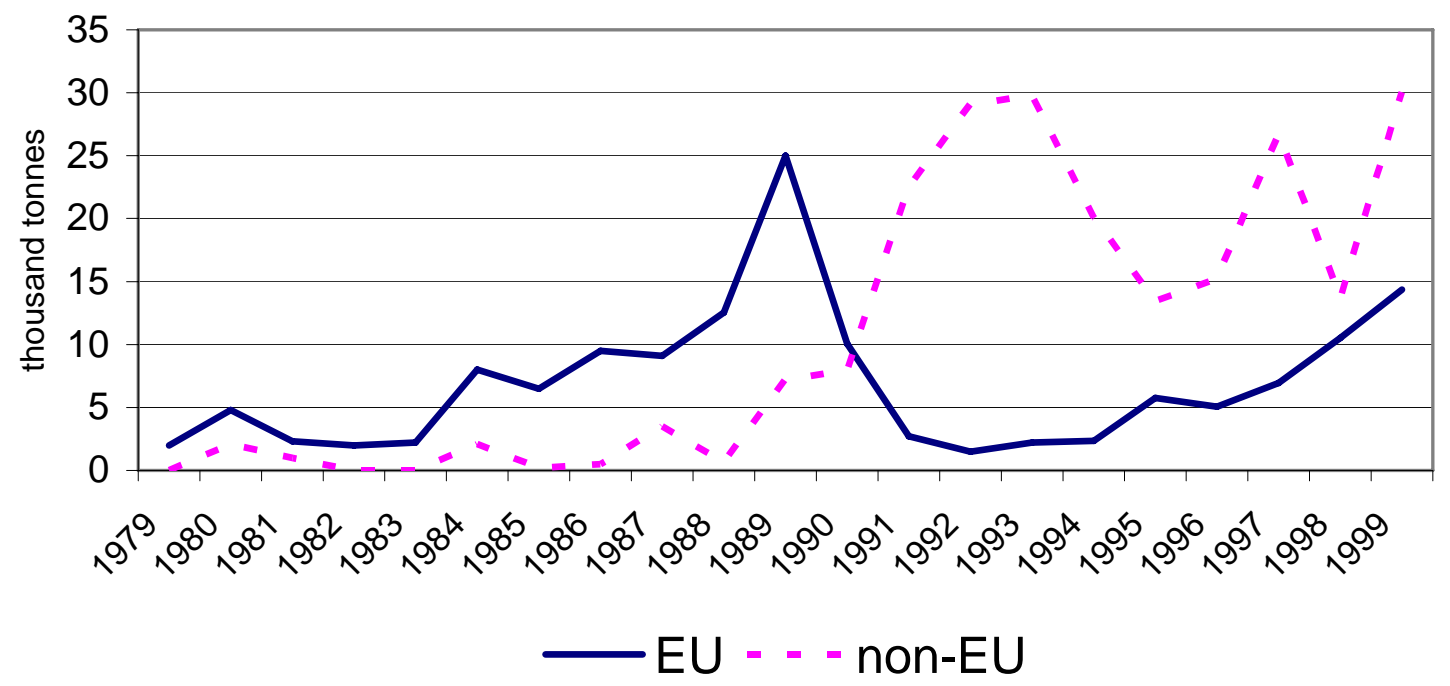

Figure 3. UK exports of flours, meats and pellets of meat or meat offal, unfit for human consumption (Source data from COMEXT and BSE Inquiry report). 


\section{Footnotes}

${ }^{1}$ While several strains of scrapie have been identified, until 2003 only one strain of the BSE prion has been found in cattle. The same strain had also been identified in other species with BSE type diseases and in humans with vCJD. Japanese and Italian researchers identified a new strain of BSE prion in October 2003. (Nature)

${ }^{2}$ Rendering is the processing of offal (organs, intestines) and other parts of the carcass to produce MBM and tallow. It involves drying, cooking, and separating solids (meal) from the melted liquid fraction (tallow).

${ }^{3}$ As of January 12, 2004 the U.K. had detected 82 cases of BSE in animals born after the 1996 feed ban. These cases are referred to as BARBs (Born After Reinforced Ban).

${ }^{4}$ In December 2002 the parents of Jonathan Simms, a Belfast, Northern Ireland, teenager suffering from vCJD, obtained permission via the courts to have their son treated with an untested drug - pentosan polysulphate. As of September 2003, doctors treating Jonathan believed that the drug had slowed the progress of the disease.

${ }^{5}$ A test using the $3^{\text {rd }}$ eyelid is used to detect scrapie in live sheep. Progress has been reported on tests that use urine and blood samples but to date there are no approved live animal tests for BSE or CWD. All references to BSE tests in this paper refer to postmortem tests on bovine brain.

${ }^{6}$ The list of countries contacted included Japan, Canada, and the US.

${ }^{7}$ Initially SBO included brain, spinal cord, tonsils, spleen, thymus and intestines from cattle more than six months old. The definition was expanded several times. In 1995 the government banned mechanically recovered meat from the spinal column.

8 This quote was from an article in Today newspaper, March 1, 1990 as referenced in Volume 6, Chapter 4, (paragraph 4.479) of the BSE Inquiry (Phillips et al.).

${ }^{9}$ In 1999, there were 31 cases in France, 91 in Ireland, 159 in Portugal, and 50 in Switzerland-compared to 2,254 in the UK 
${ }^{10}$ In 2001 and 2002, the EU tested 7.6 and 9.1 million apparently healthy animals over 30 months of age intended for human consumption.

${ }^{11}$ Data from COMEXT indicate 132, 62, 43, 31, and 64 metric tons of flour, meals and pellets, of meat or meat offal unfit for human consumption were exported from the UK to Japan annually between 1990 and 1994.

12 Japan is the only country that requires BSE tests for all cattle, regardless of age.

13 The most recent cases, in Holstein bulls aged 21 and 23 months, raise questions about the source of the disease since those animals were born after the MBM ban.

${ }^{14}$ The US is classified at level II primarily due to imports of live animals from the UK and Ireland prior to 1990 .

${ }^{15}$ Data available at: http://europa.eu.int/comm/food/fs/bse/testing/bse_results_en.html

${ }^{16}$ Pennings et al. (2002) conjecture that the US response to BSE would be similar to that of German consumers since for both the consumption decision is driven more by risk attitude than by perception of the risk level. For Dutch consumers, who did not respond as dramatically to BSE as Germans, the consumption decision was related more to risk perception than to risk attitude.

${ }^{17}$ Israel, one of the first countries to ban imports of MBM and live animals from countries with BSE, discovered its first case in June 2002.

${ }^{18}$ Adoption of the human SBO ban in the UK in 1989 is probably the only example in the BSE story of a government going beyond expert opinion in taking a precautionary measure. It turned out to be the correct decision, and likely saved thousands of people from exposure to the disease.

19 Japanese expenditures on BSE are inefficient if greater human health benefits could be obtained by applying those expenditures to other health risks e.g., food borne Salmonella. 